\title{
PERANAN SEKTOR PERTANIAN DALAM PENYERAPAN TENAGA KERJA DI PROVINSI SULAWESI UTARA
}

\author{
Angel Warouw \\ O. Esry H. Laoh \\ Gene H. M Kapantow
}

\begin{abstract}
This study aims to determine the role of agricultural sector in the absorption of labor in North Sulawesi Province. This research was conducted for three months, starting from October until December 2017 in North Sulawesi Province. In this study the data used are secondary data obtained from the Central Bureau of Statistics (BPS) of North Sulawesi Province. The data is processed using the formula Location Quotient (LQ) and Labor Multiplier (Multiplier Shortrun). The results showed that agricultural sector is the most important sector in the absorption of labor in the Province of North Sulawesi. The contribution of agriculture sector on labor absorption period 2009-2016 as much as 39\%. The contribution of the agricultural sector in absorbing labor in the Province of North Sulawesi tends to be the same as the contribution of the agricultural sector at the National level. ${ }^{*}$ ohl*.
\end{abstract}

Keywords: role of agriculture sector, employment absorption, North Sulawesi Province.

Penelitian ini bertujuan untuk mengetahui peranan sektor pertanian dalam penyerapan tenaga kerja di Provinsi Sulawesi Utara. Penelitian ini dilakukan selama tiga bulan, mulai pada bulan Oktober hingga bulan Desember 2017 di Provinsi Sulawesi Utara. Pada penelitian ini data yang digunakan adalah data sekunder yang diperoleh dari Badan Pusat Statistik (BPS) Provinsi Sulawesi Utara. Data tersebut diolah menggunakan rumus Location Quotient (LQ) dan Multiplier Tenaga Kerja (Multiplier Shortrun). Hasil penelitian ini menunjukkan bahwa sektor pertanian merupakan sektor paling penting dalam penyerapan tenaga kerja di Provinsi Sulawesi Utara. Kontribusi sektor pertanian pada penyerapan tenaga kerja periode 2009-2016 sebanyak 39\%. Kontribusi sektor pertanian dalam menyerap tenaga kerja di Provinsi Sulawesi Utara cenderung sama dengan kontribusi sektor pertanian di tingkat Nasional.*ohl*.

Kata kunci: peranan sektor pertanian, penyerapan tenaga kerja, Provinsi Sulawesi Utara.

\section{PENDAHULUAN}

\section{Latar Belakang}

Pembangunan merupakan proses perubahan yang di rencanakan dan merupakan suatu kegiatan yang berkesinambungan, berkelanjutan dan bertahap ke tingkat yang maju dan lebih baik. Untuk mewujudkan hal tersebut, maka pembangunan harus dilakukan secara bertahap di segala bidang dan sektor maupun sub sektor secara terencana dan terprogram. Salah satu cara mencapai keberhasilan pembangunan adalah dengan adanya pembangunan ekonomi.

Untuk mencapai keberhasilan pembangunan ekonomi daerah, maka suatu daerah harus mengetahui sektor apa saja yang menjadi sektor basis didaerah tersebut. Secara teoritis, meningkatnya sektor basis daerah akan meningkatkan penyerapan tenaga kerja dengan asumsi terjadi peningkatan investasi.

Kecenderungan wilayah yang berkembang dalam meningkatkan taraf hidup dan kesejahteraan masyarakatnya adalah dengan 
pembangunan di sektor pertanian, karena sektor pertanian dianggap lebih mampu meningkatkan perekonomian dan menumbuhkan berbagai kegiatan yang saling berkaitan sehingga mampu berfungsi sebagai pendorong pembangunan.

Sektor pertanian pun di arahkan untuk meningkatkan produksi pertanian guna memenuhi kebutuhan pangan dan industri dalam negeri, meningkatkan ekspor dan pendapatan petani, memperluas kesempatan kerja, serta mendorong pemerataan. Sektor pertanian merupakan salah satu sektor yang penting dalam memberikan sumbangan terhadap pertumbuhan dan pembangunan ekonomi nasional, baik dari segi pendapatan maupun penyerapan tenaga kerja.

Ketenagakerjaan merupakan salah satu hal penting yang harus di perhatikan dalam masalah pembangunan. Penyerapan tenaga kerja di perlukan dalam distribusi pendapatan yang nantinya akan berdampak pada pembangunan. Semakin besar pendapatan/upah, semakin tinggi pula tingkat penyerapan tenaga kerja di suatu sektor, dan jika seseorang ingin mencari pekerjaan pada suatu tingkat upah tertentu tetapi tidak dapat memperoleh pekerjaan yang diinginkan dan menyebabkan terjadinya pengangguran. Jika tingkat pengangguran tinggi di suatu daerah maka konsumsi masyarakat akan rendah dan akan berdampak buruk pada keberlangsungan perekonomian, dan akan berpotensi menimbulkan kearawanan seperti tindakan kriminal, gejolak sosial/politik dan kemiskinan.

Provinsi Sulawesi Utara merupakan salah satu provinsi di Indonesia yang tak lepas dari masalah pengangguran. Pengangguran adalah mereka yang digolongkan ke dalam angkatan kerja dan yang sedang mencari pekerjaan. Menurut data BPS (Badan Pusat Statistik) di Sulawesi Utara mencatat tingkat pengangguran terbuka (TPT) pada tahun 2009 sampai tahun 2016. Pada tahun 2009 tercatat pengangguran sebesar $10.65 \%$ kemudian menurun pada tahun 2010 sebesar $9.61 \%$, kembali meningkat pada tahun 2011 sebesar $10.10 \%$ kemudian terus mengalami penurunan yang baik sampai pada tahun 2016 yaitu sebesar $6.12 \%$ pengangguran. Semakin berkurangnya pengangguran dari tahun ke tahun di Provinsi Sulawesi Utara, di harapkan sektor pertanian mampu untuk menyerap tenaga kerja lebih banyak dan dapat menyediakan kesempatan kerja.

\section{Rumusan Masalah}

Berdasarkan latar belakang maka dapat ditarik rumusan masalah adalah bagaimana peran sektor pertanian dalam penyerapan tenaga kerja di Provinsi Sulawesi Utara?

\section{Tujuan Penelitian}

Berdasarkan perumusan masalah, maka yang menjadi tujuan penelitian ini adalah untuk mengetahui peran sektor pertanian dalam menyerap tenaga kerja di Provinsi Sulawesi Utara.

\section{Manfaat Penelitian} untuk:

Kegunaan penelitian ini bermanfaat

1. Bagi pemerintah Sulawesi Utara sebagai sumber informasi tentang peranan sektor pertanian di Provinsi Sulawesi Utara.

2. Bagi peneliti sebagai suatu analisis untuk mengetahui peranan sektor pertanian di Provinsi Sulawesi Utara.

3. Bagi mahasiswa dan yang memerlukan dapat bermanfaat agar dapat menambah wawasan pengetahuan, dapat dijadikan referensi kajian dalam bidang penelitian serupa serta dapat memberikan informasi tentang bagaimana penyerapan tenaga kerja pada sektor pertanian di Sulawesi Utara.

\section{METODE PENELITIAN}

\section{Waktu dan Tempat Penelitian}

Penelitian ini dilaksanakan selama tiga bulan, yaitu dari bulan Oktober sampai bulan Desember 2017 di Provinsi Sulawesi Utara.

\section{Metode Pengumpulan Data}

Data yang digunakan dalam penelitian ini adalah data sekunder. Data sekunder yang diperoleh dari Badan Pusat Statistik Provinsi Sulawesi Utara dan dinas-dinas pemerintah lainnya yang terkait. 
Konsepsi Pengukuran Variabel

Adapun variabel-variabel yang diukur dalam penelitian ini mencakup:

1. Jumlah Tenaga Kerja yang berusia 15 tahun keatas menurut Lapangan Pekerjaan Utama di Provinsi Sulawesi Utara tahun $2009-2016$.

2. Jumlah Tenaga Kerja yang berusia 15 tahun keatas menurut Lapangan Pekerjaan Utama Nasional tahun 2009 2016.

\section{Analisis Data}

\section{Location Quotient (LQ)}

Location Quotient (kuosien lokasi) atau disingkat LQ adalah suatu perbandingan tentang besarnya peranan suatu sektor atau industri di suatu daerah terhadap besarnya peranan sektor atau industri tersebut secara nasional (Tarigan, 2004).

Location Quotient (LQ) baik dalam menentukan sektor unggulan maupun sektor basis tenaga kerja. Analisis sektor unggulan dilakukan dengan membandingkan besarnya peranan suatu sektor di suatu daerah terhadap besarnya peranan sektor tersebut secara nasional. Rumus yang digunakan untuk menghitung LQ tenaga kerja adalah sebagai berikut :

Keterangan :

$$
\mathrm{LQ}_{\mathrm{ik}}=\frac{\mathrm{Xik} / \mathrm{Xk}}{\mathrm{Xip} / \mathrm{Xp}}
$$

$\mathrm{LQ}_{\mathrm{ik}}=$ Indeks Kuosien Lokasi

$\mathrm{X}_{\mathrm{ik}} \quad=$ Jumlah Tenaga Kerja Sektor

Pertanian Sulawesi Utara

$\mathrm{X}_{\mathrm{k}} \quad=$ Total Tenaga Kerja Seluruh Sektor

Sulawesi Utara

$\mathrm{X}_{\mathrm{ip}} \quad=$ Jumlah Tenaga Kerja Sektor

Pertanian Nasional

$\mathrm{X}_{\mathrm{p}} \quad=$ Total Tenaga Kerja Seluruh Sektor

Nasional

berikut:

Interpretasi rumus adalah sebagai

1. Apabila LQ tenaga kerja di sektor i lebih besar dari 1 (LQ > 1), ini berarti bahwa tenaga kerja sektor $\mathrm{i}$ di daerah studi $\mathrm{k}$ adalah lebih besar dibandingkan dengan tenaga kerja sektor yang sama di daerah refrensi p. Dengan demikian, sektor i merupakan sektor unggulan daerah studi $\mathrm{k}$ sekaligus merupakan sektor basis untuk di kembangkan lebih lanjut.

2. Apabila nilai LQ tenaga kerja di sektor lebih kecil dari 1 ( LQ < 1 ) maka sektor tersebut bukan merupakan sektor unggulan di daerah dan potensial untuk dikembangkan sebagai penggerak perekonomian daerah.

\section{Multiplier Basis Ekonomi}

Multiplier tenaga kerja di gunakan secara luas dalam proyeksi. Dengan mengevaluasi prospek masa datang dari kegiatan-kegiatan basis dalam perekonomian regional, dan menetapkan multiplier tenaga kerja (Employment Multiplier) yang di peroleh dari rasio total di bagi basis yang berhubungan dengan komposisi industri yang ada sekarang maka jumlah total kesempatan masa datang dapat diperkirakan. Rumus Multiplier Shortrun (Multiplier Jangka Pendek) yang digunakan yaitu :

$$
\mathrm{MS}=\frac{1}{1-\frac{\mathrm{NB}}{\mathrm{NB}+\mathrm{B}}}
$$

Dimana :

$$
\begin{aligned}
\text { MS }= & \text { Multiplier Shortrun } \\
& \text { (Multiplier Jangka Pendek) } \\
\text { NB }= & \text { Tenaga Kerja Sektor Non Basis } \\
\mathrm{B} & =\text { Tenaga Kerja Sektor Basis }
\end{aligned}
$$

\section{HASIL DAN PEMBAHASAN}

\section{Gambaran Umum Provinsi Sulawesi Utara}

\section{Keadaan Geografis}

Provinsi Sulawesi Utara terletak di jazirah utara Pulau Sulawesi dan merupakan salah satu dari beberapa provinsi di indonesia yang terletak di sebelah utara garis khatulistiwa, Provinsi tersebut antaranya adalah Provinsi Sumatera Utara, Kalimantan Barat, Maluku Utara, Papua Barat dan Provinsi Daerah Istimewa Aceh. Dilihat dari letak geografis Provinsi Sulawesi Utara terletak pada 00LU - 30LU dan 1230BT 1260BT. 
Provinsi Sulawesi Utara dengan Manado sebagai ibukotanya terletak antara 00015 - 05034LU dan antara 123007 127010`BT, yang berbatasan dengan Laut Sulawesi, Republik Philipina dan Laut Pasifik disebalah utara serta Laut Maluku di sebelah timur. Batas sebelah selatan dan barat masing-masing adalah Teluk Tomini dan Provinsi Gorontalo.

Luas Wilayah Sulawesi Utara tercatat $15.273 \mathrm{~km}^{2}$ yang terbagi atas 11 kabupaten dan empat kota, yakni Kabupaten Bolaang Mongondow, Kabupaten Bolaang Mongondow Selatan, Kabupaten Bolaang Mongondow Timur, Kabupaten Bolaang Mongondow Utara, Kabupaten Kepulauan Sangihe, Kabupaten Siau Tagulandang Biaro, Kabupaten Kepulauan Talaud, Kabupaten Minahasa, Kabupaten Minahasa, Kabupaten Minahasa Selatan, Kabupaten Minahasa Tenggara, Kabupaten Minahasa Utara, Kota Bitung, Kota Kotamobagu, Kota Manado dan Kota Tomohon. Bolaang Mongondow merupakan kabupaten dengan wilayah terluas, yaitu $3.022 \mathrm{~km}^{2}$ atau $19,78 \%$ dari luas keseluruhan wilayah Sulawesi Utara.

Iklim daerah Sulawesi Utara termasuk tropis yang dipengaruhi oleh angin muson. Pada bulan-bulan November sampai dengan April bertiup angin barat yang membawa hujan di pantai utara, sedangkan dalam Bulan Mei sampai Oktober terjadi perubahan angin selatan yang kering. Curah hujan tidak merata. Suhu udara berada pada setiap tingkat ketinggian makin ke atas makin sejuk seperti daerah Kota Tomohon, Langowan di Minahasa, Modoinding di Kabupaten Minahasa Selatan, Modayag dan Pasi di Kabupaten Bolaang Mongondow. Daerah yang paling banyak menerima curah hujan adalah daerah Minahasa. Suhu udara rata-rata 250C. Suhu udara maksimum rata-rata 300C dan suhu udara minimum rata-rata $22,10 \mathrm{C}$. Kelembaban udara tercatat $73,4 \%$. Kendati demikian suhu atau temperatur dipengaruhi pula oleh ketinggian tempat di atas permukaan laut. Semakin tinggi letaknya, maka semakin rendah pula suhunya, dengan perhitungan setiap kenaikan 100 meter dapat menurunkan suhu sekitar $0,60 \mathrm{C}$.

\section{Keadaan Penduduk dan Ketenagakerjaan}

Jumlah penduduk berkaitan erat dengan laju pertumbuhan penduduk. Semakin tingginya rata-rata laju pertumbuhan penduduk per tahun, otomatis akan meningkatkan jumlah penduduk secara pesat. Tingkat pertumbuhan yang tinggi pada tingkat ekonomi suatu daerah yang belum maju, dapat menimbulkan permasalahan. Pertumbuhan penduduk tinggi yang disumbangkan oleh penambahan jumlah penduduk usia muda yang belum produktif menjadi beban perekonomian secara makro dan menjadi beban rumah tangga secara mikro. Sedangkan pertumbuhan penduduk tinggi yang disumbangkan oleh penambahan jumlah penduduk usia muda yang produktif biasanya karena faktor banyaknya migrasi pencari kerja yang masuk juga tentu akan menimbulkan masalah sosial baru di suatu daerah.

Berdasarkan data penduduk tahun 2009 - 2016, jumlah penduduk dari tahun ke tahun menunjukkan terjadinya pertambahan penduduk. Jumlah penduduk dari tahun 2009 adalah sebesar 2.22 juta jiwa, kemudian pada tahun 2010 sebesar 2.27 juta jiwa. Kemudian terjadi pertambahan penduduk setiap tahunnya, sehinngga pada tahun 2015 jumlah penduduk Sulawesi Utara adalah sebesar 2.41 juta jiwa. Wilayah perkotaan dengan segala fasilitas, ketersediaan lapangan kerja, kemudahan akses, dan kelengkapan infrastrukturnya menjadi daya tarik bagi penduduk di wilayah sekitarnya. Kota Manado menempati urutan pertama dengan jumlah penduduk paling banyak di Sulawesi Utara, yaitu sebanyak 427,906 ribu jiwa. Penduduk yang paling sedikit adalah Kabupaten Bolaang Mongondow Selatan, yaitu 63,207 ribu jiwa. Dan jumlah penduduk Sulawesi Utara pada tahun 2016 terakhir adalah 2.436.921 jiwa.

Penduduk yang termasuk dalam angkatan kerja lebih banyak dari pada yang termasuk bukan angkatan kerja. Demikian juga untuk angkatan kerja, penduduk yang bekerja lebih banyak dibandingkan yang menganggur. Angkatan kerja dan bukan angkatan kerja menurut data BPS (Badan Pusat Statistik) Sulawesi Utara dimana tercatat angkatan kerja 
yang bekerja adalah sebanyak 940.173 ribu di tahun 2009 bertambah menjadi 936.939 ribu orang pada tahun 2010. Dan angkatan kerja tahun 2015 sebanyak 1.000 .032 orang sedangkan pengangguran sebesar 99.24 orang dan pada tahun 2016 sebesar 1.110 .562 orang dan semakin berkurangnya pengangguran menjadi 73.157 orang.

\section{Penduduk yang Bekerja menurut Lapangan Pekerjaan Utama di Sulawesi Utara Tahun 2009 - 2016}

Berdasarkan data Badan Pusat Statistik Sulawesi utara mengenai Jumlah Penduduk yang Bekerja menurut Lapangan Pekerjaan Utama di Sulawesi Utara 2009 - 2010 menunjukkan bahwa penduduk yang bekerja pada sektor pertanian di Sulawesi Utara mengalami fluktuasi dari tahun ke tahun, pada tahun 2009 adalah sebesar 345.595 tenaga kerja, kemudian terjadi peningkatan di tahun 2010 sebesar 357.558 tenaga kerja, lalu mengalami penurunan kembali di tahun 2011 menjadi 321.121 dan 312.137 tenaga kerja di tahun 2012, kemudian pada tahun 2013 meningkat menjadi 333.103 tenaga kerja dan kembali menurun di tahun 2014 sampai pada tahun 2015 sebesar 319.336 dan pada tahun 2016 meningkat menjadi 397.913. Meskipun tenaga kerja sektor pertanian di Sulawesi Utara terjadi fluktuasi, namun dibandingkan dengan sektor lainnya, sektor pertanian merupakan penyumbang tenaga kerja terbesar di Provinsi Sulawesi Utara disusul sektor perdagangan dan sektor jasa.

\section{Penduduk yang Bekerja menurut Lapangan Pekerjaan Utama Nasional 2009 - 2016}

Berdasarkan data Badan Pusat Statistik Sulawesi utara mengenai Jumlah Penduduk yang Bekerja menurut Lapangan Pekerjaan Utama Nasional 2009 - 2010 dapat diketahui bahwa sebagian besar penduduk Indonesia tahun 2009 - 2016 bekerja di sektor pertanian. Sektor pertanian masih menjadi sektor terbanyak dalam menyerap tenaga kerja, sektor yang menyerap tenaga kerja terbesar setelah sektor pertanian adalah sektor perdagangan dan sektor jasa-jasa.
Jumlah tenaga kerja sektor pertanian di Indonesia terjadi penurunaan selama 8 tahun terakhir. Dilihat pada tahun 2009 tenaga kerja sektor pertanian adalah sebesar 41,611,840 orang dan terus menurun hingga tahun 2016 yaitu sebesar 37,770,165 orang.

Secara umum dari tahun ke tahun peranan masing-masing sektor dalam menyerap tenaga kerja selalu berbeda. Berkembangnya suatu sektor lain diluar sektor pertanian menyebabkan banyak tenaga kerja yang beralih dari sektor pertanian ke sektor lain begitu juga sebaliknya.

\section{Jumlah Tenaga Kerja yang diserap Sektor Pertanian}

Untuk melihat tingkat daya serap tenaga kerja sektor pertanian pada tahun 2009 sampai tahun 2016 dengan mengambil data jumlah tenaga kerja sektor pertanian dan total tenaga kerja di Sulawesi Utara dan Nasional, dapat dilihat pada Tabel 1 .

\begin{tabular}{|c|c|c|c|}
\hline Tabel 1. & $\begin{array}{l}\text { Jumlah Tenaga } \\
\text { Pertanian di Sula }\end{array}$ & $\begin{array}{l}\text { erja Yan } \\
\text { i Utara Tal }\end{array}$ & $\begin{array}{l}\text { diserap Sektor } \\
2009-2016\end{array}$ \\
\hline Tahun & $\begin{array}{c}\text { Jumlah Tenaga } \\
\text { Kerja Sektor } \\
\text { Pertanian di Sulut }\end{array}$ & $\begin{array}{l}\text { Total } \\
\text { Tenaga } \\
\text { Kerja di } \\
\text { Sulut }\end{array}$ & $\begin{array}{c}\text { Kontribusi } \\
\text { Terhadap Jumlah } \\
\text { Tenaga Kerja } \\
\text { Sektor Pertanian } \\
\text { di Sulut }(\%)\end{array}$ \\
\hline 2009 & 345.595 & 940.173 & 36,75 \\
\hline 2010 & 357.558 & 936.939 & 38,16 \\
\hline 2011 & 321.121 & 990.72 & 32,41 \\
\hline 2012 & 312.137 & 957.292 & 32,60 \\
\hline 2013 & 333.103 & 965.457 & 34,50 \\
\hline 2014 & 320.963 & 980.756 & 32,72 \\
\hline 2015 & 319.336 & 1.000 .032 & 31,93 \\
\hline 2016 & 397.913 & 1.110 .564 & 35,83 \\
\hline
\end{tabular}

Berdasarkan Tabel 1 menunjukkan jumlah tenaga kerja yang terserap pada sektor pertanian di Sulawesi Utara tahun 2009 sampai tahun 2016. Tingkat daya serap tenaga kerja pada tahun 2009 mencapai $36,75 \%$ dan mengalami peningkatan pada tahun 2010 yaitu mencapai 38,16\%. Kemudian pada tahun 2011 daya serap tenaga kerja sektor pertanian menurun menjadi $32,41 \%$ dan tahun 2012 menjadi $32,60 \%$ kemudian mengalami peningkatan kembali pada tahun 2013 mencapai $34,50 \%$. Tenaga kerja yang terserap pada sektor pertanian tahun 2014 kembali mengalami penurunan menjadi $32,72 \%$ dan tahun 2015 sebesar 31,93\% dan pada tahun 2016 terjadi peningkatan mencapai $35,83 \%$ tenaga kerja. 
Dalam hal ini ada beberapa faktor yang mempengaruhi tingkat daya serap tenaga kerja pada sektor pertanian hingga terjadi fluktuasi selama periode 2009 sampai 2016 diantaranya yaitu kecenderungan masyarakat yang menaruh minat lebih pada sektor non pertanian yang diharapkan dapat memberi pendapatan yang lebih pasti karena tidak tergantung musim, hal itu di tunjukkan dengan peningkatan tenaga kerja sektor lainnya yang terus merangkak naik.

\begin{tabular}{cccc} 
Tabel 2. & $\begin{array}{c}\text { Jumlah Tenaga } \\
\text { Pertanian Nasional Tahun 2009 }\end{array}$ & $\begin{array}{c}\text { Kerja } \\
\text { 2016 }\end{array}$ \\
\hline Tahun & $\begin{array}{c}\text { Jumlah } \\
\text { Tenaga Kerja } \\
\text { Sektor }\end{array}$ & $\begin{array}{c}\text { Total } \\
\text { Tenaga } \\
\text { Kerja } \\
\text { Pertanian }\end{array}$ & $\begin{array}{c}\text { Kontribusi } \\
\text { Terhadap Jumlah } \\
\text { Tenaga Kerja }\end{array}$ \\
& Nasional & $\begin{array}{c}\text { Sektor Pertanian } \\
\text { Nasional }(\%)\end{array}$ \\
\hline \multicolumn{4}{c}{ Nonalor } \\
2010 & 41.611 .840 & 104.870 .663 & 39,68 \\
2011 & 31.494 .941 & 108.207 .767 & 38,35 \\
2012 & 39.088 .271 & 107.416 .309 & 36,39 \\
2013 & 39.590 .054 & 112.504 .868 & 35,19 \\
2014 & 38.973 .033 & 114.628 .026 & 34,78 \\
2015 & 37.748 .228 & 114.819 .199 & 33,99 \\
2016 & 37.770 .165 & 118.411 .973 & 31,90 \\
\hline
\end{tabular}

Sumber: Data Olahan

Pada Tabel 2 menunjukkan jumlah tenaga kerja yang terserap pada sektor pertanian Nasional tahun 2009 sampai tahun 2016. Tingkat daya serap tenaga kerja sektor pertanian nasional mengalami penurunan setiap tahunnya seperti yang terlihat pada tabel diatas, tahun 2009 adalah yang tertinggi yaitu mencapai $39,68 \%$ kemudian menurun pada tahun 2010 menjadi $38,35 \%$, terjadi penurunan kembali pada tahun 2011 menjadi 36,39\%, dan tahun 2012 mencapai 35,19\%, kemudian terus mengalami penurunan tahun 2013 menjadi $34,78 \%$ kemudian tenaga kerja yang terserap pada tahun 2014 adalah sebesar 33,99\% dan tahun 2015 mencapai 32,88\%, dan yang terendah dalam menyerap tenaga kerja pada sektor pertanian Nasional adalah pada tahun 2016 yaitu sebesar $31,90 \%$ tenaga kerja.

Hal ini dapat dilihat bahwa daya serap tenaga kerja sektor pertanian terjadi penurunan dari tahun ke tahun. Sektor pertanian yang menyerap tenaga kerja semakin menurun salah satunya disebabkan oleh karena adanya konversi lahan pada kota-kota besar ini meliputi keperluan untuk memenuhi kebutuhan penduduk yang semakin bertambah jumlah dan meningkatnya tuntutan akan mutu kehidupan yang lebih baik dan juga besaran upah yang lebih menarik dari sektor lain.

\section{Laju Pertumbuhan Tenaga Kerja Sektor Pertanian di Sulawesi Utara}

Hasil analisa ini untuk melihat seberapa besar laju pertumbuhan tenaga kerja pada sektor pertanian di Sulawesi Utara tahun 2009 - tahun 2016 dengan mengambil data jumlah tenaga kerja sektor pertanian dan total tenaga kerja yang di peroleh dari Badan Pusat Statistik (BPS) di Provinsi Sulawesi Utara.

\begin{tabular}{|c|c|c|c|c|}
\hline Tabel 3. & \multicolumn{4}{|c|}{$\begin{array}{l}\text { Laju Pertumbuhan Tenaga Kerja Sektor Pertanian } \\
\text { di Provinsi Sulawesi Utara Tahun 2009-2016 }\end{array}$} \\
\hline Tahun & $\begin{array}{c}\text { Jumlah } \\
\text { Tenaga } \\
\text { Kerja } \\
\text { Sektor } \\
\text { Pertanian } \\
\text { di Sulut }\end{array}$ & $\begin{array}{c}\text { Laju } \\
\text { Pertumbuhan } \\
\text { Tenaga Kerja } \\
\text { Sektor } \\
\text { Pertanian di } \\
\text { Sulut }(\%)\end{array}$ & $\begin{array}{c}\text { Total } \\
\text { Tenaga } \\
\text { Kerja di } \\
\text { Sulut }\end{array}$ & $\begin{array}{c}\text { Laju } \\
\text { Pertumbuhan } \\
\text { Total Tenaga } \\
\text { Kerja di } \\
\text { Sulut }(\%)\end{array}$ \\
\hline 2009 & 345.595 & & 940.173 & \\
\hline 2010 & 357.558 & 3,46 & 936.939 & $-0,34$ \\
\hline 2011 & 321.121 & $-10,19$ & 990.72 & 5,74 \\
\hline 2012 & 312.137 & $-2,79$ & 957.292 & $-3,37$ \\
\hline 2013 & 333.103 & 6,71 & 965.457 & 0,85 \\
\hline 2014 & 320.963 & $-3,64$ & 980.756 & 1,58 \\
\hline 2015 & 319.336 & $-0,50$ & 1.000 .032 & 1,96 \\
\hline 2016 & 397.913 & 24,60 & 1.110 .564 & 11,05 \\
\hline
\end{tabular}

Dari Tabel 3, dapat dijelaskan bahwa laju pertumbuhan tenaga kerja sektor pertanian selama periode 2009 sampai tahun 2016 cenderung negatif sedangkan laju pertumbuhan total tenaga kerja di Sulawesi Utara meningkat positif. Pada tahun 2010-2011 laju pertumbuhan tenaga kerja sektor pertanian menurun yaitu sebesar $-10,19 \%$ sedangkan total tenaga kerja di Sulawesi Utara meningkat positif sebesar $5,74 \%$. Kemudian pertumbuhan tenaga kerja sektor pertanian kembali menurun pada tahun 2011-2012 yaitu sebesar -2,79\% dan meningkat pada tahun 2012-2013 sebesar $6,71 \%$. Laju pertumbuhan tertinggi pada sektor pertanian di Sulawesi Utara yaitu pada tahun 2015-2016 sebesar $24,60 \%$ dan laju pertumbuhan total tenaga kerja sebesar $11,05 \%$

\section{Location Quotient (LQ)}

Hasil perhitungan LQ (Location Quotient) tenaga kerja dengan melihat data BPS (Badan Pusat Statistik) dihitung pada tahun 2009 sampai tahun 2016, dapat dilihat pada Tabel 4. 


\begin{tabular}{cccccc}
\hline \hline \multicolumn{7}{c}{ Tabel 4. } & \multicolumn{5}{c}{ Nilai LQ } & Tenaga & Kerja Sektor & Pertanian di Provinsi \\
& Sulawesi Utara Tahun 2009-2016 & & \\
\hline Tahun & Jumlah & Total & Jumlah & Total & \\
& Tenaga & tenaga & Tenaga & Tenaga & \\
& Kerja & kerja di & Kerja Sektor & Kerja & LQ \\
& Sektor & Sulawesi & Pertanian & Nasional & \\
& Pertanian & Utara & Nasional & & \\
& Sulawesi & & & & \\
\hline 2009 & Utara & & & & 0.92 \\
2010 & 345.595 & 940.173 & 41.611 .840 & 104.870 .663 & 0.99 \\
2011 & 357.558 & 936.939 & 41.494 .941 & 108.207 .767 & 0.99 \\
2012 & 321.121 & 990.720 & 39.088 .271 & 107.416 .309 & 0.89 \\
2013 & 312.137 & 957.292 & 39.590 .054 & 112.504 .868 & 0.92 \\
2014 & 333.103 & 965.457 & 39.220 .261 & 112.761 .072 & 0.99 \\
2015 & 319.963 & 980.756 & 38.973 .033 & 114.628 .026 & 0.96 \\
2016 & 397.913 & 10000.32 & 37.748 .228 & 114.819 .199 & 0.97 \\
\hline Sumber: Data Olahan & 11105.64 & 37.770 .165 & 118.411 .973 & 1.12 \\
\hline
\end{tabular}

Dari hasil perhitungan LQ sektor pertanian pada tahun 2009 adalah 0,92 ini menunjukkan bahwa nilai LQ lebih kecil dari 1 atau LQ < 1, kemudian pada tahun 2010 nilai LQ adalah 0,99 dan tahun 2011 adalah 0,89 ini menunjukkan nilai LQ lebih kecil dari 1 (LQ < 1) yang berarti sektor non basis, dan pada tahun 2012 nilai LQ adalah 0,92 dan 0,99 pada tahun 2013, diikuti tahun 2014 dengan nilai LQ 0,96 dan 2015 dengan nilai LQ adalah 0,97 menunjukkan nilai LQ lebih kecil dari 1 (LQ < 1) yang berarti sektor non basis. Dan nilai LQ pada tahun 2016 adalah 1,12 yang berarti LQ lebih besar dari 1 atau (LQ > 1) yang menunjukkan bahwa pada tahun 2016 adalah sektor basis.

Hasil perhitungan menunjukkan bahwa nilai LQ tenaga kerja sektor pertanian Sulawesi Utara pada tahun 2009 sampai pada tahun 2015 berada di bawah angka 1 atau LQ $<1$, dengan demikian dari aspek tenaga kerja Sektor Pertanian di Sulawesi Utara merupakan sektor non basis atau tidak potensial, kecuali pada tahun 2016 nilai LQ lebih besar dari 1 (LQ > 1), yang berarti sektor pertanian tahun 2016 adalah sektor basis yang lebih banyak menyerap tenaga kerja.

\section{Multiplier Tenaga Kerja (Multiplier Shortrun)}

Hasil perhitungan Multiplier Tenaga Kerja untuk melihat perkiraan total kesempatan kerja pada sektor pertanian masa yang akan datang, dihitung pada tahun 2009 sampai tahun 2016, dapat dilihat pada Tabel 5.
Tabel 5. Analisis Multiplier Tenaga Kerja Sektor Pertanian Provinsi Sulawesi Utara Tahun 2009 $-2016$

\begin{tabular}{cccc} 
Tahun & $\begin{array}{c}\text { Jumlah } \\
\text { Tenaga } \\
\text { Kerja Sektor } \\
\text { Basis } \\
\text { (Jiwa) }\end{array}$ & $\begin{array}{c}\text { Jumlah } \\
\text { Tenaga } \\
\text { Kerja } \\
\text { Sektor Non } \\
\text { Basis } \\
\text { (Jiwa) }\end{array}$ & $\begin{array}{c}\text { Nilai Multiplier } \\
\text { Tenaga Kerja } \\
\text { (MS) }\end{array}$ \\
\hline 2009 & 345.595 & 594.578 & \\
2010 & 357.558 & 579.381 & 2.72 \\
2011 & 321.121 & 669.599 & 3.08 \\
2012 & 312.137 & 645.155 & 3.06 \\
2013 & 333.103 & 632.354 & 2.89 \\
2014 & 320.963 & 659.793 & 3.05 \\
2015 & 319.336 & 680.696 & 3.13 \\
2016 & 397.913 & 712.651 & 2.79 \\
\hline Sumber: Data Olahan & &
\end{tabular}

Hasil analisa Multiplier tenaga kerja dengan melihat data BPS (Badan Pusat Statistik) dihitung pada tahun 2009 sampai tahun 2016.

Berdasarkan Tabel 5, menunjukkan bahwa pada tahun 2009 nilai Multiplier Shortrun (MS) adalah 2,72, nilai ini dapat di interpretasikan jika tenaga kerja sektor pertanian meningkat 100 orang, maka tenaga kerja di Sulawesi Utara akan meningkat sebanyak 272 orang. Nilai MS pada tahun 2010 mengalami penurunan, hal ini dapat dilihat dari nilai MS sebesar 2,62 yang berarti jika tenaga kerja meningkat 100 orang maka akan terjadi kenaikan sebanyak 262 orang tenaga kerja, penurunan MS di tahun ini disebabkan oleh penurunan tenaga kerja non basis. Pada tahun 2011 menunjukkan adanya kenaikan MS sebesar 3,08, angka tersebut menggambarkan terjadinya kenaikan tenaga kerja sebanyak 308 orang. Dan pada tahun 2012 dan 2013 mengalami penurunan yaitu pada tahun 2012 sebanyak 306 orang dan pada tahun 2013 sebesar 289 orang. Nilai MS pada tahun 2012 mengalami penurunan oleh karena turunnya tenaga kerja sektor basis dan non basis, dan pada tahun 2013 karena turunnya sektor non basis. Pada tahun 2014 dan 2015 menunjukkan adanya kenaikan yaitu pada tahun 2014 nilai MS adalah 3,05 jika tenaga kerja sektor pertanian meningkat 100 orang akan rmenunjukkan adanya kenaikan sebesar 305 orang tenaga kerja dan nilai MS pada tahun 2015 adalah 3,13 memberikan gambaran terjadinya kenaikan tenaga kerja sebanyak 313 jika tenaga kerja sektor pertanian meningkat 100 orang. Dan pada tahun 2016 kembali 
mengalami penurunan nilai MS yaitu 2,79 dan jika tenaga kerja sektor pertanian meningkat 100 orang akan menunjukkan adanya kenaikan sebesar 279 orang tenaga kerja di Sulawesi Utara, tahun 2016 tidak sebesar peningkatan yang terjadi pada tahun 2015 .

Hal ini dipengaruhi oleh kerena semakin tinggi kualitas sumber daya manusia di Provinsi Sulawesi Utara, dengan kata lain semakin tinggi produktif angkatan kerja, semakin tinggi peluang kesempatan kerja dan menciptakan inovasi yang menjadi kunci pertumbuhan tenaga kerja secara berkelanjutan.

\section{KESIMPULAN DAN SARAN}

\section{Kesimpulan}

Sektor Pertanian merupakan sektor paling penting dalam penyerapan tenaga kerja di Provinsi Sulawesi Utara. Kontribusi sektor pertanian pada penyerapan tenaga kerja periode 2009-2016 sebanyak 39\%. Kontribusi sektor pertanian dalam menyerap tenaga kerja di Provinsi Sulawesi Utara cenderung sama dengan kontribusi sektor pertanian di tingkat Nasional.

\section{Saran}

Saran yang dapat diberikan yaitu bagi Pemerintah daerah untuk membuat kebijakan yang tepat agar dapat lebih miningkatkan kesempatan kerja khususnya di sektor pertanian. Besarnya peluang kesempatan kerja sektor pertanian di masa yang akan datang dapat memberikan gambaran bahwa sektor pertanian memiliki potensi yang bagus untuk diandalkan.

Pemerintah Provinsi Sulawesi Utara perlu meningkatkan sarana prasarana di sektor pertanian agar tenaga kerja yang bekerja di sektor pertanian lebih maksimal dalam mengelola lahan dengan hasil yang memuaskan sehingga dapat memberikan motivasi kepada masyarakat supaya bekerja di sektor pertanian.

\section{DAFTAR PUSTAKA}

Badan Pusat Statistik (BPS) Sulawesi Utara 2009-2016. Penduduk Usia 15 Tahun Ke Atas Menurut Lapangan Pekerjaan Utama.

Badan Pusat Statistik (BPS) Sulawesi Utara 2009-2016. Penduduk Usia 15 Tahun Ke Atas Menurut Lapangan Pekerjaan Utama Nasional. 